Max-Planck-Institut für demografische Forschung

Max Planck Institute for Demographic Research

Konrad-Zuse-Strasse 1 - D-18057 Rostock · GERMANY

Tel +49 (0) 3812081 - 0; Fax +49 (0) 3812081 - 202;

http://www.demogr.mpg.de

MPIDR WORKING PAPER WP 2012-002

JANUARY 2012

\title{
The Human Capital \\ of Central-Eastern and Eastern Europe in European Perspective
}

\author{
Jörg Baten \\ Mikołaj Szołtysek (szoltysek@demogr.mpg.de)
}

(C) Copyright is held by the authors.

Working papers of the Max Planck Institute for Demographic Research receive only limited review. Views or opinions expressed in working papers are attributable to the authors and do not necessarily reflect those of the Institute. 


\title{
Jörg Baten* and Mikołaj Szołtysek**
}

\section{The Human Capital of Central-Eastern and Eastern Europe in European Perspective}

This is a preliminary version. Please do not cite without agreement of the authors. All comments warmly welcome.

\begin{abstract}
We trace the development of numeracy in Poland and Russia from the early $17^{\text {th }}$ century onwards, and numeracy in Belarus, Ukraine, and Lithuania from the $18^{\text {th }}$ century onwards. The fact that western Poland was doing relatively well during the $16^{\text {th }}$ and early $17^{\text {th }}$ centuries, but was not able to converge to Western European levels during the $17^{\text {th }}$, $18^{\text {th }}$, and early $19^{\text {th }}$ centuries, and even fell back relative to Southern Europe during this period, might support the hypothesis that the second serfdom development was one of the core factors delaying Eastern European human capital accumulation. The major wars in the region also had a devastating effect on numeracy levels.
\end{abstract}

Acknowledgements: We wish to thank Inna Vasylchuk for her very important input in the first phase of the project, and regret that she decided to leave academia and could not to become a co-author. We also wish to thank Nadine Raimann, Nicholas Meinzer, and many other students at the University of Tübingen for their able research assistance. Financial assistance was provided by the HIPOD EU program and ClioInfra (NWO). Important input came from participants of the ClioInfra meeting in Utrecht 2011.

*Univ. Tübingen and CESifo, **Max Planck Institute for Demographic Research, Rostock 


\section{Introduction}

Eastern Europe was once a region with a high standard of living, even in comparison to Western Europe. Van Zanden (1999) found that wages expressed as the purchasing power of grain were higher in the Polish cities of Warsaw and Krakow during the $16^{\text {th }}$ and early $17^{\text {th }}$ centuries (and in Lviv, which is in today's West Ukraine, during the $16^{\text {th }}$ century) than in many Western European locations. ${ }^{1}$ Using anthropometric indices, Koepke and Baten $(2005,2008)$ found Northern and Eastern European health and nutrition levels to have been more favorable than those of Western and Southern Europe. According to estimates in Koepke and Baten (2005, Table 3), during the $16^{\text {th }}$ century the average height of Eastern European men was $171.4 \mathrm{~cm}$, compared to $170.4 \mathrm{~cm}$ among the British, $169.3 \mathrm{~cm}$ among the southern Germans, and $170.0 \mathrm{~cm}$ among the "North Rhine" (Dutch/West German) people. ${ }^{2}$

However, during the $19^{\text {th }}$ century, real wages as well as human capital (which is typically correlated with income), were clearly lower in Eastern Europe. Of course, the effects of economic changes, wars, and social transformations were considerable over such a long period. What happened? And what were the determinants of these economic changes? In an attempt to answer these and related questions, we will study the development of numeracy in this region. Numeracy is clearly a core component of human capital, especially in agricultural societies, in which decisions about the timing of activities had to take a number of issues into account, such as the weather, the status of

\footnotetext{
${ }^{1}$ Of course, the cities for which evidence is available may not be representative for all of Eastern Europe. In fact, in our conclusion we will argue that western and central Poland, to which they refer, still had a remarkably high level of numeracy in the early $17^{\text {th }}$ century, which was different in other regions. ${ }^{2}$ During the 17th century, heights among Eastern European started to decline to a dramatic extent, however.
} 
plants and animals, and other similar variables. We will therefore use the techniques for measuring age-heaping in order to compare numeracy in several Eastern and CentralEastern European regions with evidence from Western and Southern Europe. Although Poland belongs to Central-Eastern Europe, we will use the term Eastern Europe in the following for reasons of brevity.

Our sources are: (1) the 'lists of souls' (either the Roman Catholic Libri Status Animarum or their Protestant Seelenregister equivalents; (2) censuses of the Civil Military Order Commissions 1790-1792 in the territories of Poland-Lithuania; (3) the Russian 'revizii' (tax-oriented censuses); (4) the censuses of 1897 in Russia and 1880 in Prussia and Austria-Hungary; and (5) other types of household listings, including 'communion books' and local administrative surveys, as well as private and Crown estate inventories.

These sources allow us to estimate numeracy in several regions of what is today Poland, Belarus, Ukraine, Lithuania, and Russia. The application of age-heaping-based numeracy estimates to this newly available data set is performed here for the first time for such a large region and the time frame (but see Mironov 1991 and Kaiser and Peyton 1993 on Russian samples). Given the regional character of our sources, we decided to aggregate the numeracy estimates using today's national borders rather than historical empires or other regional units. This will allow for the comparison of the estimates with other historical evidence in the future (such as GDP estimates, anthropometric welfare, and other indicators).

The remainder of the study is organized as follows. We first review some findings and hypotheses of the previous literature regarding the reasons why Eastern Europe 
lagged behind Western Europe in educational and welfare levels. In the second section, we present our new data set and explain its capabilities and limitations. In Section 3, we briefly explain the age-heaping methodology, as well as some caveats and doubts scholars may have about it. We also provide some of the responses to potential criticism of age-heaping proponents. In Section 4, we report the results at the regional level and present a method that can be used to adjust for regional biases. Finally, in Section 5, we

present the national estimates for the five Eastern European countries since the $17^{\text {th }}$ century, and compare these estimates with evidence from Western and Southern Europe. Finally, we present a tentative discussion of the implications of our findings for our understanding of early modern economic growth.

\section{Review of the literature}

In his study of literacy rates around 1800, Reis (2005) reported substantially lower values for Hungary (six percent), which is the only Eastern (or Central-Eastern) country he documented. This value was substantially lower than in other European countries. A very long-run study on Russian literacy was performed by Mironov (1991). He cited the estimate by the Russian historian Sapunov that a mere one to 1.5 percent of the Russian population in the mid- $13^{\text {th }}$ century may have been literate before the Mongol invasion (based on the assumption that monks, clergymen, and the upper strata of secular society were literate). Mironov reported that, by the end of the $17^{\text {th }}$ century, the number of books, records, and similar literacy-related items had increased. Literacy estimates based on the signatures of witnesses in legal sources yielded a very rough literacy rate of between two and 2.5 percent for the late $17^{\text {th }}$ century. Finally, by organizing the 1897 census (which 
also reported literacy) by birth cohorts, he arrived at an estimate of four percent around 1800 and 13 percent around 1850. Literacy might have been 30 percent around 1900. In contrast, the literacy rates in Western Europe were estimated at between 15 and 65 percent in the early modern period until around 1800 (A'Hearn et al. 2009, p. 802). Mironov also looked at local samples of Baltic peasants and other sources to assess the degree of age-heaping, but did not organize the data by birth cohorts of adults. Kaiser and Peyton (1993), who studied the urban communities of Tula and Viatka around 1700, unearthed very important evidence, but also did not conduct a cohort analysis. A'Hearn et al. (2009) argued that Eastern Europe lagged behind the West in numeracy.

What might have caused the relatively low Eastern European educational levels in the $19^{\text {th }}$ century, as well as the relatively modest welfare levels? A number of prominent explanations for the adverse development of Eastern Europe have been given in the previous literature.

a) Hajnal famously argued that differences in the age at marriage and other aspects of household formation behavior differed between Eastern and Western Europe. He identified a border at the line St. Petersburg-Trieste, which might have left most of the Baltic and Western Poland in the 'Western' part; and Ukraine, Russia, Belarus, and eastern Poland in the 'Eastern' part. It is possible that early marriage might have resulted in less educational investment per child. As early as in 1970, Hajnal's observations had been rejected as being too simplistic by J. Sklar in her dissertation, and several other scholars have criticized them harshly in a number of more recent studies (Sklar 1970, Plakans and Wetherell 2005, Szołtysek 2004, 2007, 2008a, 2008b, 2009, Szołtysek and Zuber-Goldstein 2010). But despite this criticism, the Hajnal hypothesis remains a 
persistent stereotype in economic history, as well as in demographic literature. Some of this discussion might be about the traditional dividing line between economists, who tend to accept simplifications and the statistical concept of the average; and family historians, who adhere to more nuanced and contextualized perspectives stressing micro- and mesolevel variation.

But the East-West divide could also have been caused by other factors mentioned below. We should note upfront that the Hajnal hypothesis is considered here with very strong reservations.

b) A lack of "girl power" (de Moor and van Zanden 2010, similarly ForemanPeck 2011) may have also played a role. De Moor and van Zanden have argued that in the West, and especially in the North Sea region, women had more customary rights in the labor market and in other aspects of family economies (such as inheritance; see, however, Guzowski 2010 and Dennison 2011 for criticism). Educational gender inequalities might have led to less education on average, as women were mainly responsible for basic education in the household.

c) The second serfdom hypothesis is another classic in the economic history literature (Kula, 1976; Millward 1982; Cerman 2008; Ogilvie and Edwards 2000). In particular, historical Poland and Russia have been regarded as typical cases of noble landlordism and village subjection (Hagen, 1998; also Mironov, 1996). ${ }^{3}$ The massive growth in landlord powers over the rural population in these areas was closely related to a rapid rise in agricultural commodity values in the West caused by the 16 th-century 'price

\footnotetext{
${ }^{3}$ These were: juridical subjection, migration regulations, legal attachment to a particular social status, subjection to communal payments and duties (including the most harsh compulsory labour), limited right to private property, limited choice of occupation, and unprotected personal dignity; see Mironov, 1996, p. 323.
} 
revolution'. The Eastern European landowners responded to this trend by expanding their previously modest familial manor farms into large-scale domanial economies designed to produce surpluses for sale on the urban markets of Western Europe. This type of seigneurialism prompted landlords to demand from their peasant subjects not only rents in cash and kind, but above all labor services, which were essential to the very functioning of the demesne farms (Szołtysek 2008a). Serfs therefore had less incentive and ability to invest in basic education, such as the numeracy concept applied in this study. Of course, serfdom has taken on very different forms. The most extreme form was the manorial system based on peasants' personal and hereditary subjection, as well as on their labor obligations (corvée) to the manors. This system was introduced in the territories of Poland-Lithuania during the $16^{\text {th }}$ to early 17 th centuries; however, the strongest manorial system developed in western Poland and in some parts of Ukraine (esp. Volhynia). On the other hand, there have always been areas where this type of serfdom could never have been fully introduced (Polessia in Belarus; Subcarpathian Ukraine). For example, in wide areas of the historical Grand Duchy of Lithuania, a softened version of the system-based on cash quitrents rather than on corvée, or a mixture of the two- emerged in the second half of the $17^{\text {th }}$ century and prevailed until the end of the Polish republic in 1795 (Szołtysek 2008a, 2008b).

As a minor digression from the literature review, we will look briefly at the regional distribution of serfs, as opposed to free or manumitted persons, and people on government-owned estates.

An overwhelming majority of the population of all of the territories under investigation lived in personal and hereditary subjection up until the 19th-century 
reforms, with their property rights limited to an indeterminate leasehold. This fact notwithstanding, it has been observed that the share of hereditary or emphyteutic freeholders, or peasants holding more advantageous property rights, diminished considerably and progressively when moving into Polish eastern territories and Russia (Rutkowski, 1986; Moon 1999). If we consider the distribution in the share of serfs in the Russian Empire during mid- $19^{\text {th }}$ century, a clear regional pattern also emerges (Figure 4). ${ }^{4}$ Especially in a central corridor between Belarus (Minsk) and Nishniy Novgorod, the share of serfs was particularly large. In contrast, the thinly populated regions in the Northeast had few serfs, and the same is true for the Southeast. Moreover, the Southeast was characterized during the late serfdom period by the slightly less oppressive system of Barshchina, in which feudal obligations were paid in money or kind, whereas the corvée system of compulsory labor was more typical in other regions. The share of serfs actually corresponds quite well to the regional distribution of numeracy and literacy (Figure 2 and $3)$.

d) Large-farm agriculture is often associated with a political economy in which large landowners prevented tax-financed public schooling, as they saw no need for serfs to learn (and perhaps demand political rights) in schools financed by the taxes of the rich. Similar considerations apply to agricultural laborers later on, after the abolition of serfdom. $^{5}$

e) Likewise, the political governance of the Russian Empire did not favor schooling, and the situation in eastern Russia was similar. The Russian Empire was

\footnotetext{
${ }_{5}^{4}$ Note, however, that no data are provided for Polish territories.

5 'Agricultural laborers' were only part of socioeconomic landscape of Eastern Europe for the period after the formal abolition of serfdom; they emerged quite early in Galicia due to Josephinian reforms of 1780s, and then in the province of Greater Poland (Prussian Province of Posen) after the 1820s.
} 
dominated by the landed interests of its nobility. Hence, investment in schooling was not very high on the national agenda, at until the empire lost the Crimean War. During this major event, not just the military inferiority of Russia, but also the empire's backwardness in terms of productivity and human capital became obvious. Thereafter, the government implemented reforms which also initiated a trend towards investing in larger-scale schooling.

f) The long-run consequences of wars and civil wars might have been a risk aversion among the population regarding investments of any sort. The terrible damage caused by the mid- $17^{\text {th }}$-century wars, soon repeated during the 1720 s, brought the development of the manorial economy and the land-labor ratio to levels not very different to those of the late 17th century; i.e., at the beginning of the agrarian change (Szoltysek 2008a).

d) Lower life expectancy might have had the same effect. Life expectancy at birth, $\mathrm{e}$, was probably lower in this part of Europe than in the West, although our evidence for this assumption is still relatively weak. At least for historical Poland, this is only a tentative argument based on single case studies using different methodologies; it is widely believed that values of 27 for males and around $27-28$ for women were typical in Eastern Europe in the late $18^{\text {th }}$ century, whereas some West European countries reached values above 30 (Kuklo 2009).

h) Low population density and the lack of a transport system made commuting to schools more costly and returns on schooling lower; of course, this only refers to the statistical average, and to the East in particular. There were regions in historical Poland with quite substantial population densities, such as Lesser Poland around Krakow, 
Galicia, or some regions close to the Baltic Sea under the Royal Prussia. The $17^{\text {th }}$-century wars cut deep wounds in terms of population densities as well. The regions of western and central Poland, as well as of western Galicia, generally represented the most populated areas of the country. Moving to the eastern areas, we observe a gradual decrease in population density; in late $18^{\text {th }}$-century Belarus, it was definitely below 10 persons $/ \mathrm{km}^{2}$.

i) Religion: Could the absence of Protestantism, or the lack of religious competition, have played a role (Baten and van Zanden 2008)? While most of Slavic Russia was Orthodox, the religious pattern was more mixed in the West. Calvinism emerged among the Polish nobility in the $16^{\text {th }}$ century and dominated this political class well into the mid- $17^{\text {th }}$ century, or even longer; the western fringes of Poland were inhabited by religiously mixed communities, with a substantial share of Protestants (mainly settlers from different parts of Germany and the Netherlands). The degree of religious fractionalization was much lower in the Polish eastern 'borderlands' throughout the early modern period (Szady 2010, 228-250). Even there, however, religiously mixed communities or regions could be found, with the peasantry dominated by Uniates (and later members of the Orthodox faith), and not seldom intermingled with islets of Polishspeaking minor nobility. There was also a substantial Jewish population. Similarly important in this context could be the competition between the Uniates and the Orthodox believers, on the one hand; and the Catholics and the Protestants on the other (Mitterauer 2003).

Some of these potential determinants will be discussed below using interregional comparisons, while others will be discussed using East-West comparisons. However, the 
aim of the present paper is not to perform a regression in which these potential explanations are systematically tested against each other.

\section{Sources}

Our sources are: (1) the 'lists of souls' (either the Roman Catholic Libri Status Animarum or their Protestant Seelenregister equivalents; (2) the censuses of the Civil-Military Order Commissions 1790-1792 in the territories of Poland-Lithuania (which were occupied by the Russian Empire after the late $18^{\text {th }}$ century); (3) the Russian revizii (tax-oriented censuses); (4) the censuses of 1880 in Prussia and Austria-Hungary (which had occupied other territories of modern Poland) and 1897 in Russia; and (5) other types of household lists, including 'communion books' and local administrative surveys, as well as private and Crown estate inventories. ${ }^{6}$

In Table 1, we report on the places and regions for which evidence is available. In the second column, we list the country in which the regional unit is situated today. In the following three columns, we indicate the county, the larger district, and the empire in which these places were situated towards the later $19^{\text {th }}$ century. It should be noted that, of the places situated in Prussia or Austria-Hungary, we included only those with a large majority of Polish speakers. This was done to avoid placing German-speaking communities in the category of 'today's Poland', as their descendants might later have

\footnotetext{
${ }^{6}$ All these sources, except for 19 th-century censuses and the 17 th $/ 18^{\text {th }}$-century sources on Russia, are the part of the CEURFAMFORM Database developed by M. Szoltysek. The database development was supported by the Marie Curie Intra-European Fellowship project (FP6-2002-Mobility-5, Proposal No. 515065) at the Cambridge Group for the History of Population and Social Structure, Cambridge, UK, 20062008. More details in Szołtysek 2008a, 2008b.
} 
fled or been moved to Germany after WWII. In the ethnic overlap between Poland, Lithuania, and Belarus, we have been less restrictive. There might be some migration biases later on. We also took care not to include any sources in which some crosschecking by priests or officials might have taken place. In those cases, there was almost no heaping present. We only included county-birth decade averages that were based on at least 50 observations (for the number of cases, see an appendix available from the authors).

\section{Assessing human capital formation with the age-heaping indicator and other}

\section{measures of human capital}

Measuring the production factor 'human capital' has never been simple, as advanced forms of skills are difficult to compare. All economists have therefore resorted to the use of proxy indicators, such as the share of people signing a marriage register. Grundlach (2001) noted that the empirical measurement of the human capital factor and the productivity of education in economic growth performed in human capital research up to this point are still not completely satisfying. A comparison of different proxy indicators might perhaps be the best option for obtaining reliable insights. This is the rationale for using the age-heaping methodology (as well as comparisons of literacy and schooling, wherever they are available to us). We will explain the advantages and caveats in somewhat greater detail, as the application of this method in economic history is still relatively new.

This approach employs the set of methods that developed around the phenomenon of 'age-heaping'; i.e., the tendency of poorly educated people to round their age 
erroneously. For example, less educated people are more likely than people with a greater endowment of human capital to state their age as " 30 ," even if they are in fact 29 or 31 years old (Mokyr 1985). ${ }^{7}$ Crayen and Baten (2008) found that the relationship between illiteracy and age heaping for LDCs after 1950 is very close. They calculated age-heaping and illiteracy for not less than 270,000 individuals who were organized by 416 regions, ranging from Latin America to Oceania. The correlation coefficient with illiteracy was as high as 0.7 . The correlation with the PISA results for numerical skills was as high as 0.85 ; hence, the age-heaping measure "Whipple Index" is more strongly correlated with numerical skills. A'Hearn, Baten, and Crayen (2009) used a large U.S. census sample to perform a very detailed analysis of this relationship. They subdivided the sample by race, gender, high and low educational status, and other criteria. In each case, they obtained a statistically significant relationship. It is also remarkable that the coefficients are relatively stable between samples; i.e., a unit change in age heaping is associated with similar changes in literacy across the various tests. Those results are not only valid for the U.S.: in all of the countries studied so far that had substantial age-heaping, the correlation was found to be both statistically and economically significant. ${ }^{8}$

In order to assess the robustness of those U.S. census results and the similar conclusions which could be drawn from the less developed countries of the late 20th century, as mentioned in the introduction to this study, A'Hearn et al. (2009) also assessed age-heaping and literacy in 16 different European countries between the middle ages and the early 19th century. Again, they found a positive correlation between age

\footnotetext{
${ }^{7}$ Among demographers, this specific type of age misreporting constitutes "one of most frustrating problems" (Ewbank 1981, 88). It is treated as a source of distortion in age-specific vital rates which needs to be removed, or at least minimized in order to study the family or household variables.

${ }^{8}$ On the regions of Argentina, see, for example, Manzel, Baten, and Stolz (forthcoming).
} 
heaping and literacy, although the relationship was somewhat weaker than for the 19thor 20th-century data. It is likely that the unavoidable measurement error when using early modern data induced the lower statistical significance. ${ }^{9}$

The possibly widest geographical sample studied so far has been created by Crayen and Baten (2010), who were able to include 70 countries for which both ageheaping and schooling data (as well as other explanatory variables) were available. They found in a series of cross-sections between the 1880s and 1940s that primary schooling and age-heaping were closely correlated, with R-squares between 0.55 and 0.76 (including other control variables, see below). Again, the coefficients were shown to be relatively stable over time. This large sample also allowed for the examination of various other potential determinants of age-heaping. To assess whether the degree of bureaucracy, birth registration, and government interaction with citizens is likely to influence the knowledge of one's exact age, independent of personal education, Crayen and Baten used the number of censuses performed for each individual country up to the period under study as an explanatory variable for their age-heaping measure. Except for countries with a very long history of census taking, all of the variations of this variable turned out to be insignificant, which would suggest that such an independent bureaucracy effect was rather weak. In other words, it appears to be the case that societies with a high number of censuses and an early introduction of birth registers had a high degree of age awareness. But those societies also introduced schooling early, and this was the variable

\footnotetext{
${ }^{9}$ The experience of historical demographers shows that data from premodern times were often very rough, imprecise, or fragmentary. Even the18th century statistical materials are still a sheer jungle of uncertainties and traps, as they were not seldom collected haphazardly and analyzed without sill; as a result, they often embrace just part of the phenomenon which they refer to, are thus incomplete (Szołtysek 2011). This refers in particular to the quality of data on age.
} 
that clearly had more explanatory power than the independent bureaucracy effect. Crayen and Baten also tested whether the general standard of living had an influence on ageheaping tendencies (using height as well as GDP per capita as welfare indicators), and found a varying influence: in some decades, there was a statistically significant correlation, while in others there was none.

Was this correlation between numeracy and literacy also visible in Eastern Europe? When comparing the log literacy in the Russian Imperial census of 1897 for the individuals born between 1825 and 1884 on the vertical axis, and their numeracy levels (see Figure 3, expressed by the ABCC index) on the horizontal axis, we can see that there is a clear correlation. The Baltic governments of Estland and Livland, as well as the capital region of St. Petersburg, featured very positively, whereas the 'serfdom'-intensive regions around Belarus had quite low values of both literacy and numeracy. ${ }^{10}$ Interestingly, the northeastern districts of European Russia-such as Archangelsk, Wologda, and Perm-were much better in numeracy than they were in literacy. The previous literature has noted that, for literacy development, the existence of schools is even more important than for basic numeracy. For the latter, education in the family contributes more in relative terms. In the thinly populated regions of the northeast, gaining access to schools was much more difficult than in the more densely populated areas farther south.

In conclusion, the correlation between age-heaping and other human capital indicators is quite well established, and the 'bureaucratic' factor does not invalidate this relationship. A caveat relates to other forms of heaping (apart from the heaping on

\footnotetext{
${ }^{10}$ Please note that, as serfdom was abolished on all these territories in 1864 , a potential impact must have stemmed from the first four decades. An outlier is the district of Kowno.
} 
multiples of five), such as heaping on multiples of two, which is quite widespread among children and teenagers and to a lesser extent among young adults in their twenties. ${ }^{11}$ This shows that most individuals knew their age as teenagers, but that only in well-educated societies were they are able to remember or calculate their exact age later in life. At higher ages, this heaping pattern was mostly negligible, but it was, interestingly, somewhat stronger among populations who were numerate enough not to round on multiples of five. We will exclude those below age 23 and above 72 since a number of possible distortions affect those specific age groups, leading to age reporting behavior different from that of the adult group in between. Many young males and females married in their early twenties or late teens, when they also had to register as voters, military conscripts, etc. On such occasions, they were sometimes subject to minimum age requirements, a condition which gave rise to increased age awareness. Moreover, individuals in this age group were physically growing, which makes it easier to determine their age with a relatively high accuracy. All of these factors tend to deflate age-heaping levels for children and young adults, compared with the age reporting of the same individuals at higher ages. Because the age-heaping pattern of very old individuals is subject to upward as well as downward bias for the reasons mentioned above, the very old should also be excluded.

There remains some uncertainty about whether age-heaping in the sources contains information about the numeracy of the responding individual, or rather about the diligence of the reporting personnel who wrote down the statements. The age data of the

\footnotetext{
${ }^{11}$ It has been shown that, in some societies, in addition to the usual overrepresentation of five and zero, there was also a decided preference for figures ending on other digits, whereas avoidance of some numbers was likely to occur in a patterned way as well (Stockwell 1966; Nagi, Stockwell and Snavley 1973).
} 
relevant age groups of 23-72 were normally derived from statements from the person himself or herself. However, it is possible that a second party, especially the husband, may have made or influenced the age statement, or even that the enumerator estimated the age without asking the individual. If the latter occurred, we would not be able to measure the numeracy of the person interviewed. In contrast, if the enumerator asked and obtained no response, a round age estimated by him would still measure basic numeracy correctly. A large body of literature has investigated the issue of other persons reporting. Foldvari et al. (2011) speculated, for example, that wives may appear to have been more numerate than they actually were because they improved their age statement with the help of their husbands. They compared the numeracy of married and unmarried women and found that the latter had significantly lower numeracy in some of their samples. However, de Moor (2011) recently rejected this view with a number of good arguments. Moreover, in the early modern period and the $19^{\text {th }}$ century, marriage was often associated with higher educational and social status, as a number of studies have found (for example, Baten and Murray 1998). We compared male and female numeracy in our sample, and found that women were sometimes more numerate than men, which would support the hypothesis that they reported their age themselves. On the other hand, there is a correlation between the male and female numeracy of different households. Recently, Friesen et al. (2011) compared systematically the evidence of a gender gap in numeracy and in literacy for the late $19^{\text {th }}$ and early $20^{\text {th }}$ centuries, and found a strong correlation. They argued that there is no reason why the misreporting of literacy and age should have yielded exactly the same gap between genders. A more likely explanation is that the wellknown correlation between numeracy and literacy also applies to gender differences. For 
our study, the question of whether the women answered themselves is slightly less important, because we only seek to estimate average numeracy.

Moreover, there is sometimes direct evidence in the sources that the wives themselves were asked. Manzel et al. (2011) reported finding sources on Latin American Indio women in which statements like this one were included: "She says that she is 30 , but she looks more like 40." Even for black female and male slaves in the Cape Colony in South Africa who were accused of crimes, the legal personnel created a separate column that indicated whether the person was guessing her age, or whether she actually knew. It is possible that, if those Indio and African women, who probably were not shown much respect by colonial officers, were asked for their age; then European women might also have been asked for their age, as the level respect shown to them might have been somewhat greater.

The problem of different enumerators influencing the quality of age statements has also been studied in a $20^{\text {th }}$-century context. While a large part of age misreporting indeed arises because the respondents do not know their exact age, this problem is likely to be exacerbated by differences in the quality of the performance of the enumerators, as some of them may have taken their duties more seriously than others (United Nations $1952,59)$. Referring to the notorious hardships encountered in the surveying processes in contemporary developing countries, Ewbank observed: "In particular, the training of interviewers, their level of education, and their ability to understand and pursue the interests of the researcher will significantly affect the quality of data [on age]" (Ewbank 1981, 15). However, the difference between the behavior of $20^{\text {th }}$-century enumerators and the priests and officials of the $17^{\text {th }}$ to $19^{\text {th }}$ century is that the former had much easier 
access to sources that would enable them to cross-check age statements. Priests of the $18^{\text {th }}$ century could have looked up birth years in birth registers, but because the registers

were usually chronologically sorted, the cross-checking of ages would have required a substantial investment of time. Still, some of the existing sources were clearly crosschecked (yielding ABCC values of around 100 very early), and hence we used a historian's judgment in excluding them. In addition, Szołtysek (2011) found that differences in the age-heaping patterns in historical Poland-Lithuania might be partly amenable to explanation by referring to different organizing principles of the enumeration process inherent to different types of listings.

Of course, a potential bias always exists if more than one person is involved in the creation of a historical source. For example, if literacy is measured by analyzing the share of signatures in marriage contracts, there might have been priests who were more or less interested in obtaining real signatures, as opposed to just crosses or other symbols. We find it reinforcing that previous studies have generally found much more age-heaping (and less numeracy) among the lower social strata, and among the half of the sample population who had lower anthropometric values (Baten and Mumme 2010). Moreover, the regional differences of age-heaping are similar to the regional differences in illiteracy. It can be concluded that the method of age-heaping is a useful and innovative tool for assessing human capital.

\section{Results at the regional level and the adjustment of regional biases}


We present the $\mathrm{ABCC}$ estimates for the individual regions in Table A.1 in the appendix. ${ }^{12}$ On the left side of Table A.1, the new regional estimates for the period of the 1630 s to 1810 s are presented; while on the right side, the 1820 s to 1900 s estimates are given. The latter are based on the 1880 and 1897 population census and later censuses, while the former set of figures is based on the sources mentioned in the data section. For Russia, five regions can be documented, sometimes for very different periods. To what degree are those regions representative? The fact that Moscow is included in the five documented regions suggests that there is probably upward bias. Hence the next logical question would be: Did the regions have $\mathrm{ABCC}$ values similar to the average of Russia in the 1897 census? Or, how large was the upward bias? In fact, four out of the five regions had ABCC values 15-25 percent above the Russian average (Column "Adjustment factor"). Only the Eyskij location in the Kuban territories south of Rostov/Don was similar to the Russian average for the birth decade of the 1820 s. Hence, we need a regional adjustment. For simplicity, we take the difference for the birth cohort of the 1820s, and report the regionally adjusted values in Table A.2 in the appendix. This adjustment is based on the assumption that the interregional bias was similar in the early period and for the birth decade of the 1820 s. This might not have been the case for all of the regions, but in general the estimate will be closer to the true national average after the adjustment than before. The fact that we normally have four to five different regional

\footnotetext{
${ }^{12}$ The ABCC Index reports a society's share of individuals who probably know their true age (named after A'Hearn, Baten and Crayen, as well as Greg Clark, who developed that measure). The formula is

$A B C C=\left(1-\frac{(W h-100)}{400}\right) \times 100$ if $W h \geq 100 ;$ else $A B C C=100$.

The index ranges from 0 to 100. If everybody reports the correct age, ABCC has a value of 100 .
} 
data sets to compare allows us to gain an impression of the size of measurement error implied by this procedure. For example, in the case of Przemyshlany and the birth decade of the 1730s, the resulting value is clearly too low; also, the Warsaw region might have been underestimated for the $18^{\text {th }}$ century. But in the vast majority of cases, the regional adjustment procedure works relatively well. In order to remain consistent, we take all of the values into account.

\section{Estimates for the five Eastern European countries and international comparison}

In a next step, we generate national estimates based on those regional values. In Figure 5, we display the regional and national estimates for Russia. Some of the early estimates are above and others are below the estimate for Russia, but the emerging trend seems relatively clear. Hence we show the national trends for all five countries in Figure 6. We distinguish between the western and eastern parts of today's Poland. The western part is made up of East Silesia and other parts of Prussia (only Polish speakers), as well as of

those districts that were annexed by Prussia and Austria-Hungary in the $18^{\text {th }}$-century partitions of Poland. The eastern part consists of the regions that were occupied by the Russian Empire. We were curious about whether the west and east would yield similar estimates for the whole of Poland after being regionally adjusted to the national mean. In fact, the similarity of level suggests that this division does not affect the estimates for Poland significantly, even if the variation over time is not identical.

Finally, our aim was to make those series graphically comparable with estimates for other European regions. This was achieved by using the LOWESS procedure, which 
was previously used by Manzel et al. (2011). In order to make the comparison, the eastern and western parts of Poland were considered together (Figure 7).

\section{Eastern Europe in international comparison}

What broad trends do we obtain from this procedure, and how do they compare with those of other European regions? In Figure 8, data from Eastern Europe were plotted against the evidence from Western and Southern European countries, which we derived from Stolz et al. 2012 (see also Tollnek and Baten 2011). The authors assessed the Northwestern European region (Austria, Germany, France, Sweden, and the UK), for which relatively continuous evidence from the 1730 s is available, and the Southern European region (Italy, Spain, Portugal). Both series start at around 80 percent numeracy in the early $18^{\text {th }}$ century, but the Northwestern region made more rapid progress, and achieved 95 percent numeracy around 1800. The Northwest had solved the basic numeracy problem by around the middle of the $19^{\text {th }}$ century. Numeracy in Southern Europe stagnated at a quite high level of around 82 percent from the 1730s until the 1820s, and then slowly converged with Northwestern European levels. Earlier evidence

suggests that, during the $15^{\text {th }}$ century, numeracy levels varied across Europe from 72 percent $\mathrm{ABCC}$ in the Netherlands, to 55 percent in Northern Italy, to 40 percent in Germany, and down to 18 percent in Southern Italy (A'Hearn et al. 2009). Juif and Baten (2011) found that Spain and Portugal had numeracy levels of around 60 percent both in the early and the late $17^{\text {th }}$ century.

Hence, the Northwestern and Southern European regions were clearly more numerate than all of the Eastern European regions we are assessing here during the $18^{\text {th }}$ 
and $19^{\text {th }}$ centuries, although during the $17^{\text {th }}$ century Poland did not differ very much from the European South (Juif and Baten 2011). Moreover, the trends of convergence and the slowdown in the individual regions are interesting. Russia started at a much lower level than Portugal, or at around 20 percent in the early $17^{\text {th }}$ century, but the gap between Russia and Poland had declined to less than five percent in the mid- $18^{\text {th }}$ century. During the $19^{\text {th }}$ century, human capital again started to accumulate, and the problem of basic numeracy was almost solved around 1900.

Poland displayed stagnant levels of numeracy throughout much of the $17^{\text {th }}$ and early $18^{\text {th }}$ centuries (around 60), whereas the European South grew by some 20 ABCC points during this period. Basic trends in numeracy continued to increase in Poland during the middle decades of the $18^{\text {th }}$ century. During the $19^{\text {th }}$ century, a steady upward trend can be discerned in all of the Eastern European regions.

Among the countries studied here, Belarus, Lithuania, and Ukraine lagged behind the most. During the early to mid- $18^{\text {th }}$ century, numeracy still stood at around 20 percent in Lithuania, 40 percent in Belarus, and 50 percent in Ukraine. Ukraine then started a rapid development, which resulted in Ukrainian numeracy levels overtaking Russian levels during the $19^{\text {th }}$ century. It would be interesting to assess whether the migration of Jewish people from the Polish-Lithuanian regions to Ukraine also stimulated this surge in Ukrainian numeracy. Belarus and Lithuania experienced the most rapid growth in their numeracy levels during the $19^{\text {th }}$ century.

The relatively large discrepancy between Polish and Russian levels early on, and the much greater dissimilarity of the former in relation to the territories of Belarus, Lithuania, and Ukraine during the $18^{\text {th }}$ century, are among the major findings here. 


\section{Results and Conclusion}

Serfdom seems to have played a key role in limiting human capital development in Eastern Europe, as is apparent in the regional patterns we discussed in the digression from the literature review. The earliest evidence we have on western Poland suggests that, in the early $17^{\text {th }}$ century, the region was not very far behind other regions of Europe. For example, it displayed a numeracy level similar to those of Portugal and Spain in 1600-49 and 1650-99 (Juif and Baten 2011). By contrast, Russia was probably at a much lower level during this period, whereas Belarus, Ukraine, and Lithuania started at very low levels when our evidence becomes available in the $18^{\text {th }}$ century. The fact that western Poland was still doing relatively well during the early $17^{\text {th }}$ century, but was not able to converge to Western European levels during the $17^{\text {th }}, 18^{\text {th }}$ and early $19^{\text {th }}$ centuries, and even fell back relative to Southern Europe during this period, might support a second serfdom hypothesis.

In addition to being impeded by wars, which also affected other regions of Europe, such as Central and Southern Europe; educational progress in Eastern Europe might have been hindered by the second serfdom tendencies which continued in the $17^{\text {th }}$ and $18^{\text {th }}$ centuries. 


\section{References}

A'Hearn, Brian, Baten, Jörg, and Crayen, Dorothee and "Quantifying Quantitative Literacy: Age Heaping and the History of Human Capital" Journal of Economic History 69-3 (Sept 2009), pp.783-808.

Baten, Jörg and Christina Mumme: "Globalization and Educational Inequality in LongRun Development during the 17th to 20th Centuries: Latin America and other Developing World Regions", Journal of Iberian and Latin American Economic History 28-2 (2010), 279 -305. doi:10.1017/S021261091000008X.

Baten, Jörg and John Murray (1998). "Women's Stature and Marriage Markets in PreIndustrial Bavaria", Journal of Family History 23-2, pp. 124-135

Baten, Jörg and Jan Luiten van Zanden (2008): "Book Production and the Onset of Early Modern Growth", Journal of Economic Growth 13-3, pp. 217-235,

Cerman, M. (2008). Social structures and land markets in late medieval central and eastern-central Europe.Continuity and Change 23(1), 55-100.

Crayen, Dorothee and Baten, Jörg "New Evidence and New Methods to Measure Human Capital Inequality before and during the Industrial Revolution: France and the U.S. in the 17th to 19th Centuries "Economic History Review 53-2 (2010), pp. 452-478.

Crayen, Dorothee and Baten, Jörg "Global Trends in Numeracy 1820-1949 and its Implications for Long-Run Growth", with Dorothee Crayen, Explorations in Economic History 47-1 (2010), pp. 82-99 doi:10.1016/j.eeh.2009.05.004.

Crayen, Dorothee and Joerg Baten (2008): Global Trends in Numeracy 1820-1949 and its Implications for Long-Run Growth, CESifo Working Paper 2218. [Extended Working Paper version of Crayen and Baten 2010]

De Moor, Tine (2011). Art History and Numeracy\#if

De Moor, Tine and Jan Luiten van Zanden (2010) Girl power: the European marriage pattern and labour markets in the North Sea region in the late medieval and early modern period, Economic History Review 63-1, pp. 1-33.

De Moor, Tine, and Van Zanden, J.-L., 'Uit fouten kun je leren. Een kritische benadering van de mogelijkheden van 'leeftijdstapelen' voor sociaal-economisch historisch onderzoek naar gecijferdheid in het pre-industriële Vlaanderen en Nederland', Tijdschrift voor Economische en Sociale Geschiedenis, 5 (2008), pp. 55-86. 
Dennison, T. (2011). Household formation, institutions, and economic development: Evidence from imperial Russia. The History of the Family Volume 16, Issue 4, 456465.

Ewbank, Douglas C. (1981), Age misreporting and age-selective underenumeration: sources, patterns, and consequences for demographic analysis. Committee on Population and Demography, Report No. 4, Washington, D.C.: National Academy Press.

Friesen, Julia, Joerg Baten and Valeria Prayon: "Women count. Gender (In-)Equalities in the Human Capital Development in Asia, 1900-1960", Working Paper Univ. Tuebingen.

Guzowski, P. (2010). European Marriage Pattern in Central Europe: the case of late mediewal and Early modern Poland. Paper presented at the $35^{\text {th }}$ Annual Meeting of the Social Science History Association (SSHA), Palmer House Hilton, Chicago, Illinois (USA), November 2010.

Hagen, W.W. (1998). Village life in East-Elbian Germany and Poland, 1400-1800: subjection, self-defense, survival. In T. Scott (ed.), The peasantries of Europe from the fourteenth to the eighteenth centuries (pp. 145-190). London: Longman.

Juif, Dácil-Tania and Joerg Baten (2011) “On the Human Capital of 'Inca' Indios before and after the Spanish Conquest” Working Paper Univ. Tuebingen

Kaiser, Daniel and Peyton Engel. "Time- and Age-Awareness in Early Modern Russia." Comparative Studies in Society and History 35, no. 4 (1993): 824-39.

Koepke, Nikola and Joerg Baten (2005), "The Biological Standard of Living in Europe During the Last Two Millennia," European Review of Economic History 9-1 (2005), pp. 61-95

Koepke, Nikola and Jörg Baten (2008) "Agricultural Specialization and Height in Ancient and Medieval Europe", Explorations in Economic History 45 (2008), pp. 127-146.

Kuklo, C. (2009). Demografia Rzeczypospolitej przedrozbiorowej. Warszawa: DiG.

Kula, W. (1976). An economic theory of the feudal system: towards a model of the Polish economy, 1500-1800. London: N.L.B. 
Lyashchenko, Peter I. (1949). History of the National Economy of Russia to the 1917 Revolution, tr. Leon M. Herman. New York: Macmillan.

Manzel, Kerstin, Stolz, Yvonne, Baten, Jörg "Convergence and Divergence of Numeracy: The Development of Age Heaping in Latin America, 17th to 20th Century", Economic History Review (2012, forthcoming).

Millward, R. (1982). "An economic analysis of the organization of serfdom in Eastern Europe.” Journal of Economic History, 42, 513-48.

Mironov, Boris N. (1991). The Development of Literacy in Russia and the USSR from the Tenth to the Twentieth Centuries. History of Education Quarterly, Vol. 31, No. 2. (Summer, 1991), pp. 229-252.

Mironov, B.N. (1996). When and why was the Russian peasantry emancipated? In M.L. Bush (Ed.), Serfdom and slavery: studies in legal bondage (pp. 324-347). Harlow : Longman.

Mironov, Boris N., 'Novaya Istoricheskaya Demografia Imperskoy Rossii: Analycheski obsor Corremennoy Istoriografii', Vestnik Sankt-Peterbursgskovo Universiteta, 4 (2006), pp. 62-90.

Mitterauer, Michael: Warum Europa? Mittelalterliche Grundlagen eines Sonderwegs. München 2003

Moon, D. (1999). The Russian peasantry, 1600-1930: the world the peasants made. London \& New York: Longman.

Nagi, M. H., E. G. Stockwell, and L. M. Snavley (1973). Digit Preference and Avoidance in the Age Statistics of Some Recent African Censuses: Some Patterns and Correlates. International Statistical ReviewVol. 41, No. 2, pp. 165-174.

Nafziger, Steven "Communal Institutions, Resource Allocation, and Russian Economic Development: 1861-1905," The Journal of Economic History (June 2008): 570-575.

Nafziger, Steven "Peasant Communes and Factor Markets in Late Nineteenth-Century Russia," Explorations in Economic History 47.4 (2010): 381-402.

Ogilvie, S., J. S. S. Edwards (2000). Women and the Second Serfdom: Evidence from Early Modern Bohemia. Journal of Economic History, 60, 961-994. 
Plakans, A. \& Wetherell, C. (2005). The Hajnal line and Eastern Europe. In T. Engelen \& A.P.Wolf (Eds.), Marriage and the family in Eurasia. Perspectives on the Hajnal hypothesis (pp. 105-126). Amsterdam: Aksant.

Reis, Jaime. "Economic Growth, Human Capital Formation, and Consumption in Western Europe Before 1800." In Living Standards in the Past, edited by Robert C. Allen, Tommy Bengtsson, and Martin Dribe, 195-225. Oxford: Oxford University Press, 2005.

Rutkowski, J. (1986 [1921]). Poddaństwo włościan w XVIII wieku w Polsce i niektórych innych krajach Europy. In J. Rutkowski, Wieś europejska późnego feudalizmu, selected and edited by J. Topolski (pp. 25-215). Warszawa: PIW.

Stockwell, Edward G. (1966). Patterns of digit preference and avoidance in the age statistics of some recent national censuses : a test of the Turner hypothesis. Eugenics quarterly 13(3), 205-208.

Stolz, Yvonne, Joerg Baten and Jaime Reis "Portuguese Living Standards 1720-1980 in European Comparison - Heights, Income and Human Capital", Economic History Review (2012, forthcoming)

Szady, B. (2010). Geografia struktur religijnych $i$ wyznaniowych $w$ Koronie $w$ drugiej połowie XVIII wieku. Lublin: Wydawnictwo KUL.

Szoltysek, M. (2004). Astride the Hajnal line - household and family in the Upper Silesian parish of Bujakow, 1766-1803. Polish Population Review, 11, 59-93.

Szoltysek, M. (2007). Central European household and family systems, and the "HajnalMitterauer" line: the parish of Bujakow (18th-19th centuries). The History of the Family, 1, 19-42.

Szołtysek, M. (2008a). Three kinds of preindustrial household formation system in historical Eastern Europe: A challenge to spatial patterns of the European family. The History of the Family, 13 (3), 223-257.

Szołtysek, M. (2008b). Rethinking Eastern Europe: household formation patterns in the Polish-Lithuanian Commonwealth and European family systems. Continuity and Change, 23, 389-427. 
Szołtysek, M. (2009). Life cycle service and family systems in the rural countryside: a lesson from historical East-Central Europe. Annales de Démographie Historique, 1, 53-94.

Szołtysek, M. (2011). „A sheer jungle of uncertainties and traps”: uses and misuses of premodern census microdata. Paper presented at the Seminar of Economic History, University of Tübingen, Department of Economics (Germany), June 2011.

Szołtysek, M., and B. Zuber Goldstein, (2010). Historical family systems and the great European divide: the invention of the Slavic East. Demográfia: English Edition, 52(5), 5-47.

Tollnek, Franziska and Joerg Baten (2011). "The Farmer's U: Which Occupational Group Inherited Human Capital in Early Modern Europe and Latin America?" Working Paper Univ. Tuebingen

Van Zanden, Jan Luiten (1999). "Wages and the Standard of Living in Europe, 15001800“ European Review of Economic History, August 1999, v. 3, iss. 2, pp. 175-97 
Table 1: Places and provinces included (period before 1880/1897)

\begin{tabular}{|c|c|c|c|c|c|}
\hline \multirow[b]{2}{*}{ Place/County } & \multirow{2}{*}{$\begin{array}{l}\text { Country } \\
\text { today }\end{array}$} & \multirow{2}{*}{\multicolumn{2}{|c|}{ County $1880 / 1897$}} & \multicolumn{2}{|l|}{ Adm. Gouv./Province } \\
\hline & & & & $1880 / 1897$ & Empire \\
\hline Bobrujski & by & Bobrujskij & & Minskaja & Poland/Russia \\
\hline Lelowski & $\mathrm{pl}$ & Chenstohovskij & & Petrokovskaja & Poland/Russia \\
\hline Charkov & ua & Charkov & & Charkov & Russia \\
\hline Crakow & $\mathrm{pl}$ & $\begin{array}{l}\text { Cracow } \\
\text { Hauptmannschaft) } \\
\text { Cracow }\end{array}$ & $\begin{array}{l}\text { (Bezirks- } \\
\text { (Bezirks- }\end{array}$ & Galizien & $\begin{array}{l}\text { Austria- } \\
\text { Hungary } \\
\text { Austria- }\end{array}$ \\
\hline Proszowski & $\mathrm{pl}$ & Hauptmannschaft) & & Galizien & Hungary \\
\hline Olsztynski & $\mathrm{pl}$ & Ermland-Masuren & & Koenigsberg & Prussia \\
\hline Mozyrski & by & Gomel'skij & & Mogilevskaja & Russia \\
\hline Koscian & $\mathrm{pl}$ & County in Greater Po & and & Posen & Prussia \\
\hline Kaliski & $\mathrm{pl}$ & Kaliskij & & Kaliskaja & Poland/Russia \\
\hline Kruszwicki & $\mathrm{pl}$ & Kaliskij & & Kaliskaja & Poland/Russia \\
\hline Ostrzeszowski & $\mathrm{pl}$ & Kaliskij & & Kaliskaja & Poland/Russia \\
\hline Wielunski & $\mathrm{pl}$ & $\begin{array}{l}\text { Kaliskij } \\
\text { Kossow }\end{array}$ & (Bezirks- & Kaliskaja & $\begin{array}{l}\text { Poland/Russia } \\
\text { Austria- }\end{array}$ \\
\hline Kossow & ua & Hauptmannschaft) & & & Hungary \\
\hline Radziejowski & $\mathrm{pl}$ & County in Greater Po & and & Posen & Prussia \\
\hline Sepólno & $\mathrm{pl}$ & County in Greater Po & and & Posen & Prussia \\
\hline Wyrzysk & $\mathrm{pl}$ & $\begin{array}{l}\text { County in Greater Po } \\
\text { Limanowa }\end{array}$ & $\begin{array}{l}\text { and } \\
\text { (Bezirks- }\end{array}$ & Posen & $\begin{array}{l}\text { Prussia } \\
\text { Austria- }\end{array}$ \\
\hline Olesnicki & $\mathrm{pl}$ & Hauptmannschaft) & & Galizien & Hungary \\
\hline Leczycki & $\mathrm{pl}$ & Lodzinskij & & Petrokovskaja & Poland/Russia \\
\hline Krasnystaw & ua & Lublinskij (East) & & Lublinskaja & Poland/Russia \\
\hline Minski & by & Minskij & & Minskaja & Poland/Russia \\
\hline Nieswieski & by & Minskij & & Minskaja & Poland/Russia \\
\hline Nowogrodzki & by & Minskij & & Minskaja & Poland/Russia \\
\hline Slucki & by & Minskij & & Minskaja & Poland/Russia \\
\hline Wilejka & by & Minskij & & Minskaja & Poland/Russia \\
\hline Bytomski & $\mathrm{pl}$ & Opole & & Opole & Prussia \\
\hline Siewierski & $\mathrm{pl}$ & Opole & & Opole & Prussia \\
\hline Dawidgrodecki & by & Pinskij & & Minskaja & Poland/Russia \\
\hline Malborski & $\mathrm{pl}$ & $\begin{array}{l}\text { Pomerania } \\
\text { Przemyshlany }\end{array}$ & (Bezirks- & Koeslin & $\begin{array}{l}\text { Prussia } \\
\text { Austria- }\end{array}$ \\
\hline Przemyslany & ua & Hauptmannschaft) & & Galizien & Hungary \\
\hline Wilenski & It & Vilenskij & & Vilenskaja & Poland/Russia \\
\hline Kcynski & $\mathrm{pl}$ & Warschavskij & & Warschavskaja & Poland/Russia \\
\hline Eyskij & ru & Eyskij & & Kuban territory & Russia \\
\hline Moskovskij & ru & Moskovskij & & Moskovskij & Russia \\
\hline Orenburgskij & ru & Orenburgskij & & Orenburgskij & Russia \\
\hline Tulskij & ru & Tulskij & & Tulskij & Russia \\
\hline Vjatskij & $\mathrm{ru}$ & Vjatskij & & Vjatskij & Russia \\
\hline
\end{tabular}


Figure 2: Numeracy in the governments of the Russian Empire (ABCC index)

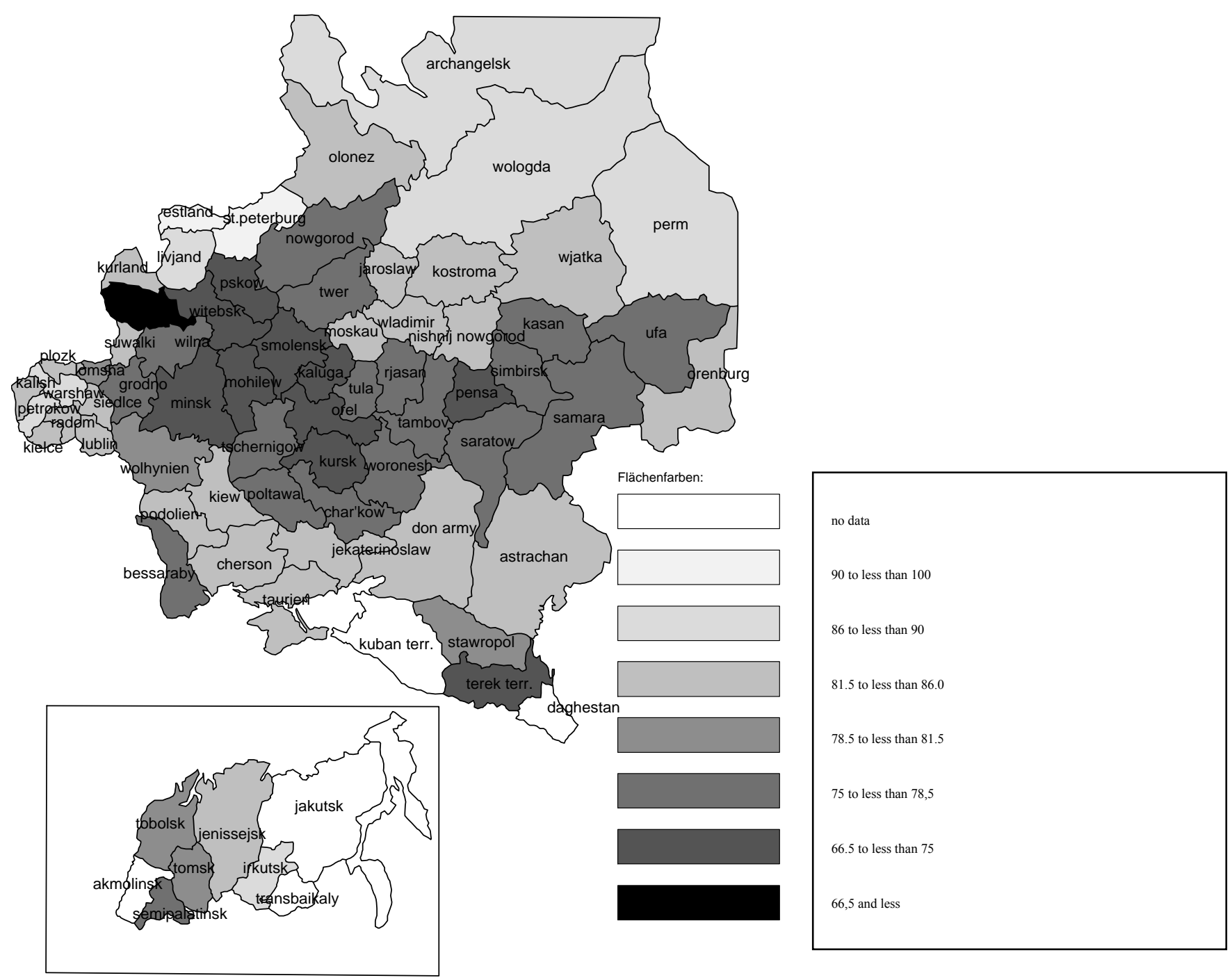

Note: It refers to individuals born between 1825 and 1874 . The black value of Kovno is probably an outlier. 
Figure 3: Comparison of Literacy and Numeracy in the governments of the Russian Empire (ABCC)

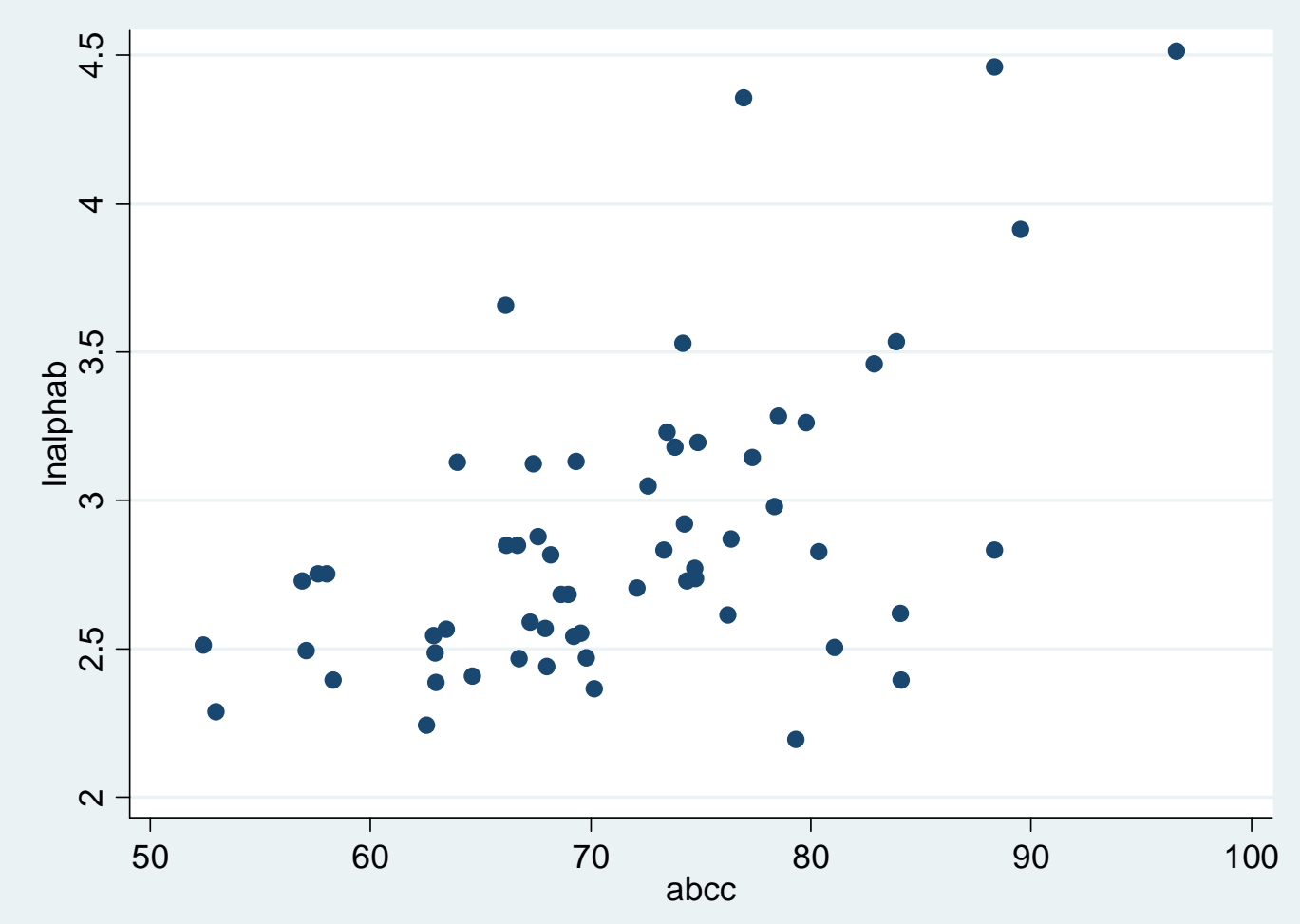

Note: It refers to individuals born between 1825 and 1884. 
Figure 4: Serfdom in the Russian Empire

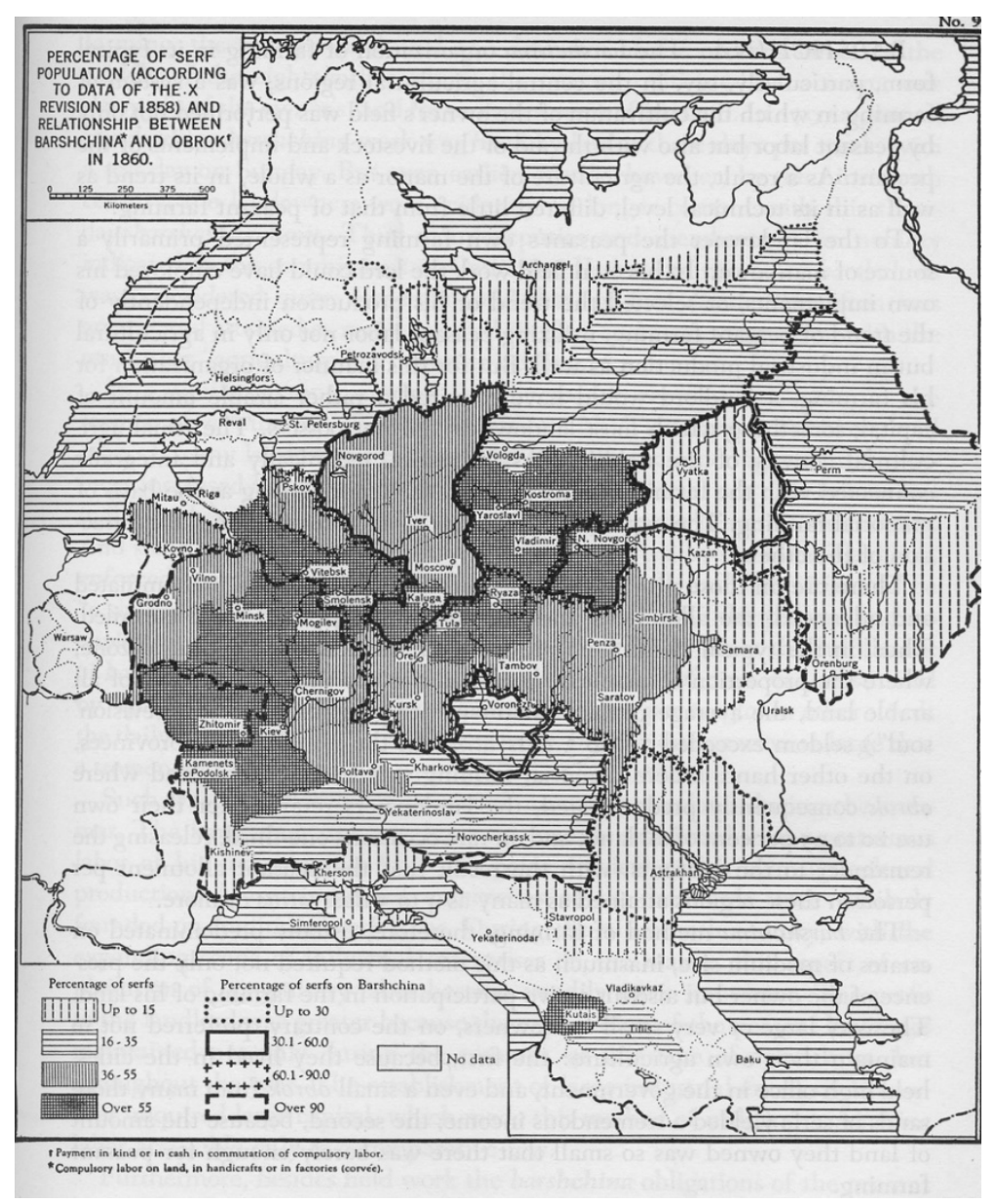

Source: Lyashchenko (1949) 
Figure 5: Regionally adjusted numeracy $(\mathrm{ABCC})$ of places in Russia

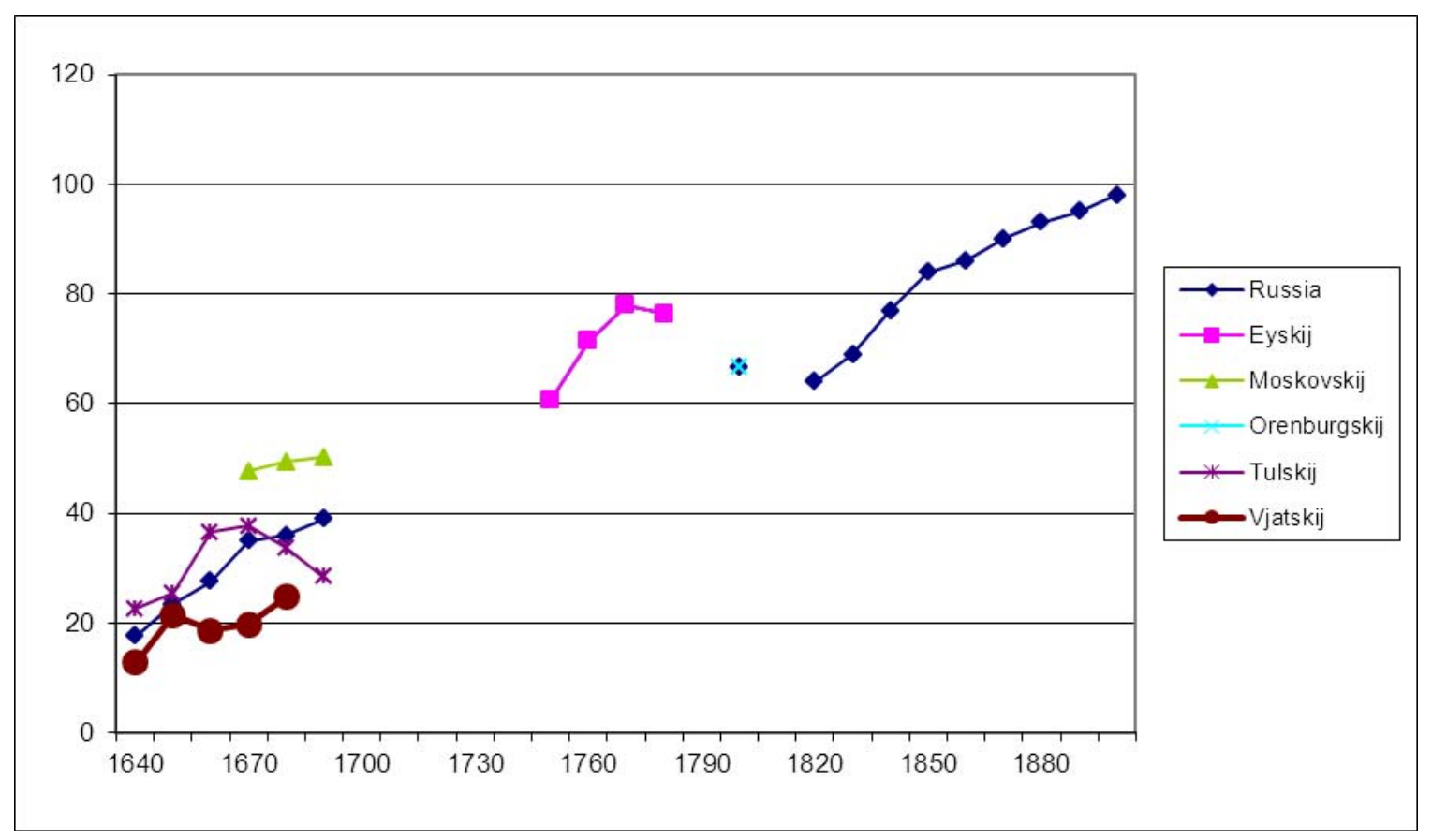


Figure 6: $\mathrm{ABCC}$ country trends
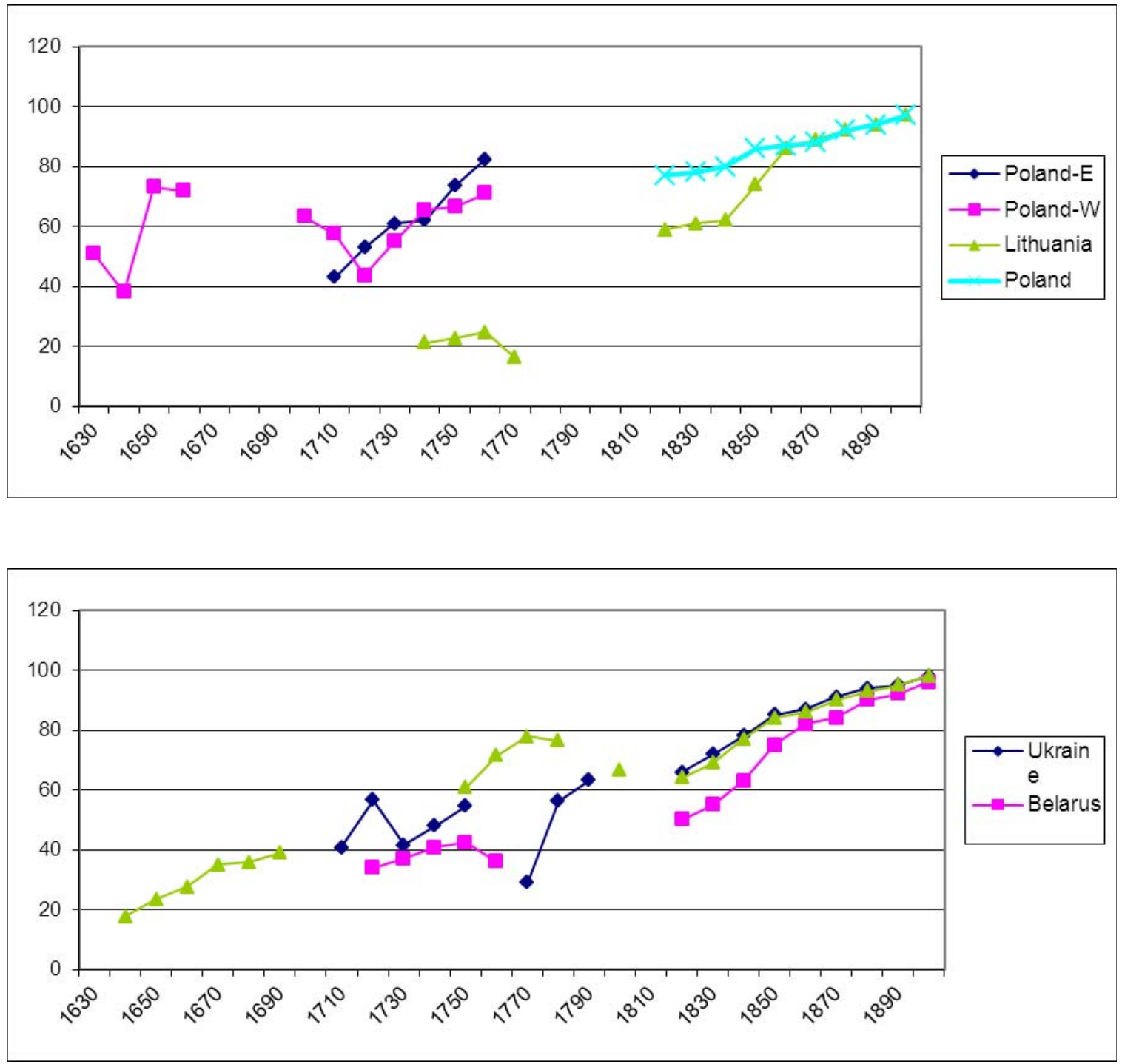
Figure $7:$ LOWESS-smoothed ABCC trends:

Belarus:

\section{Lowess smoother}

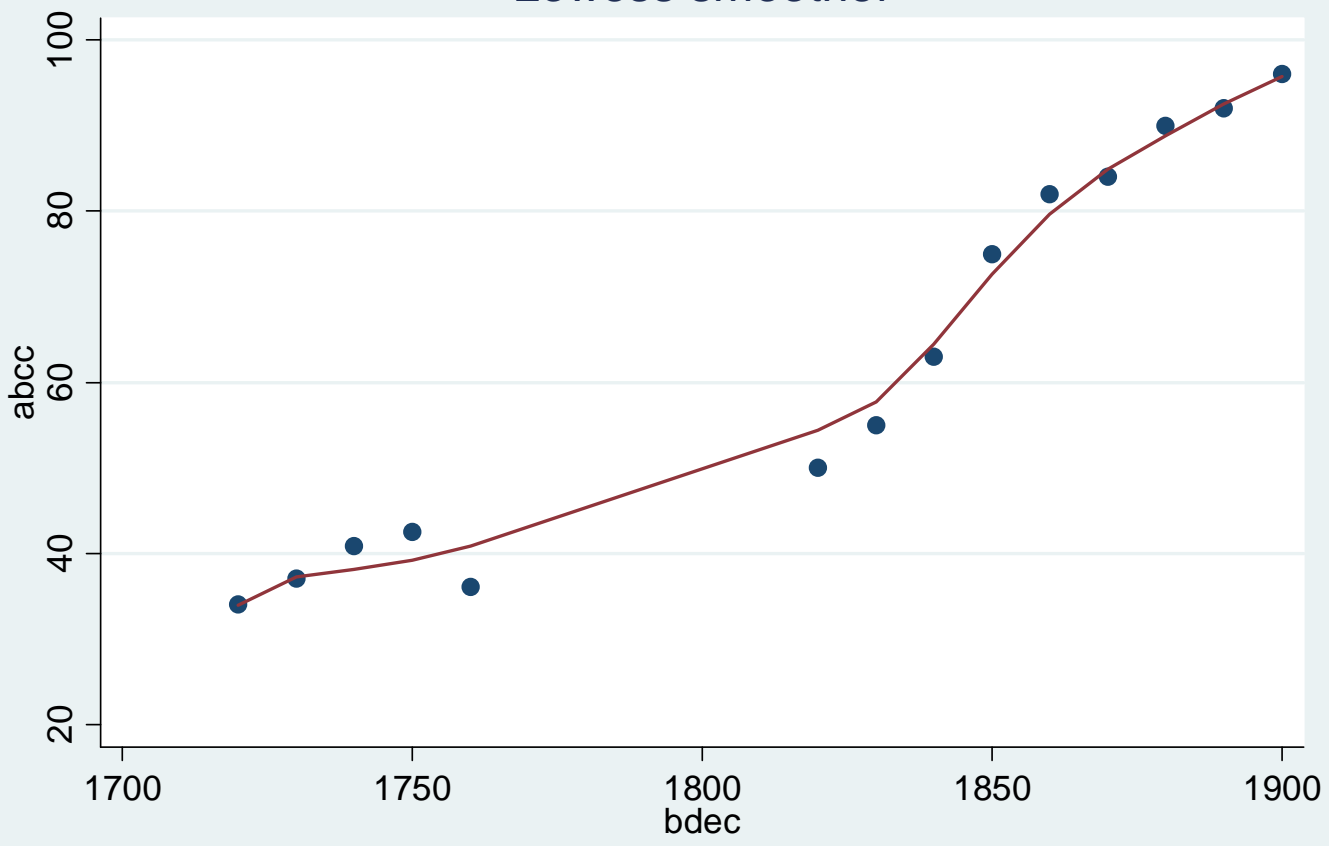

bandwidth $=.5$

Lithuania:

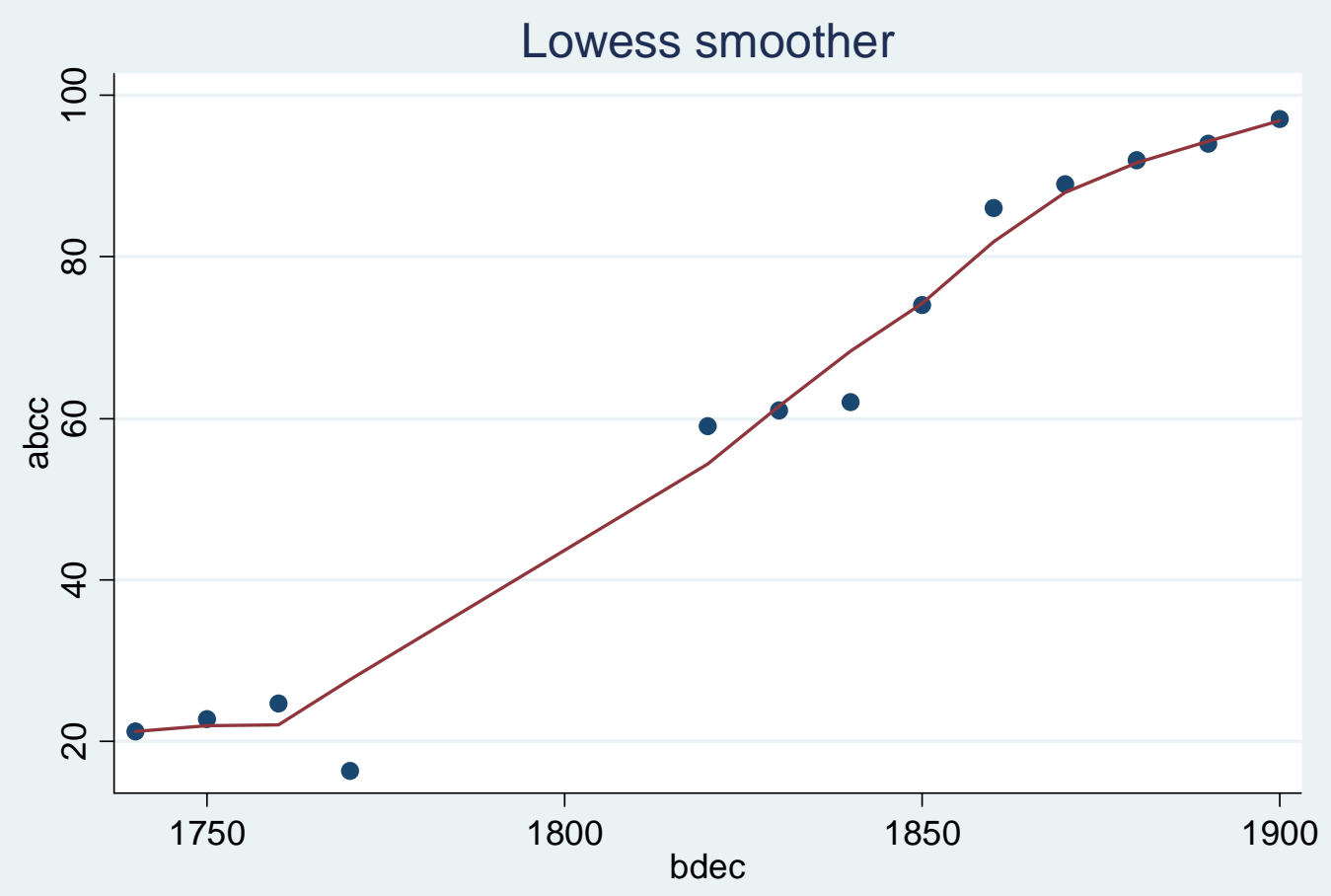

bandwidth $=.5$ 
Poland:

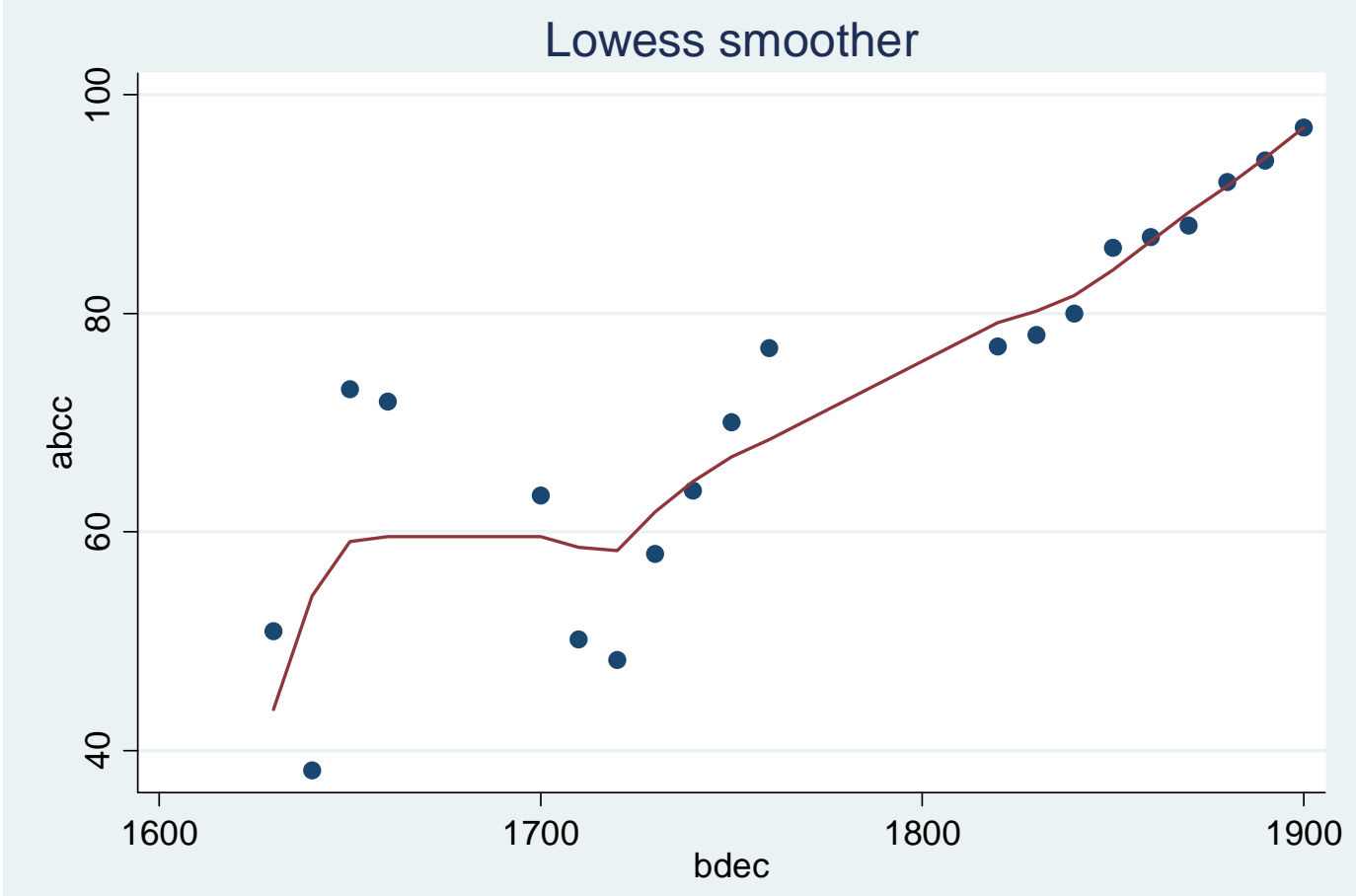

bandwidth $=.5$

Russia:

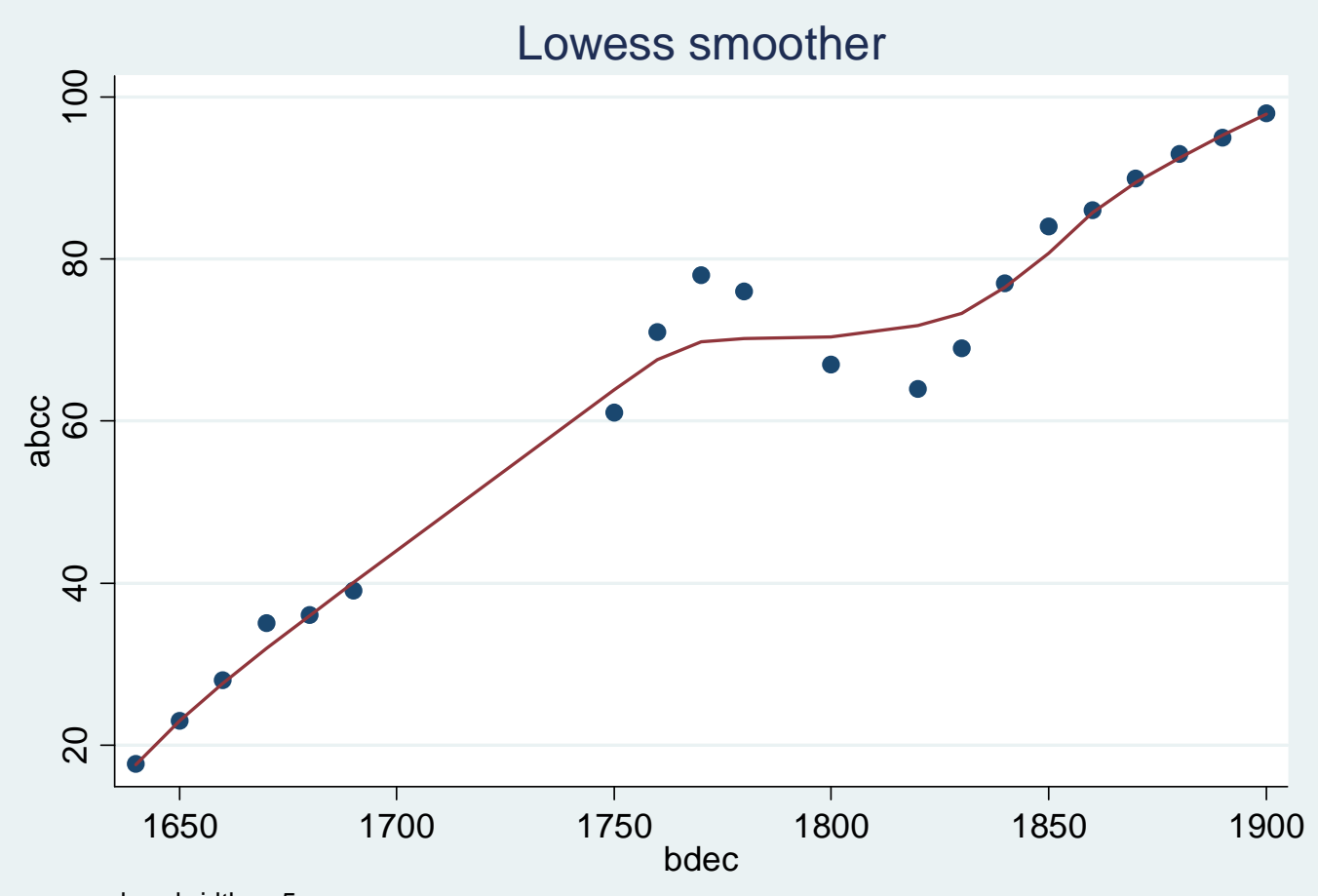

bandwidth $=.5$ 
Ukraine:

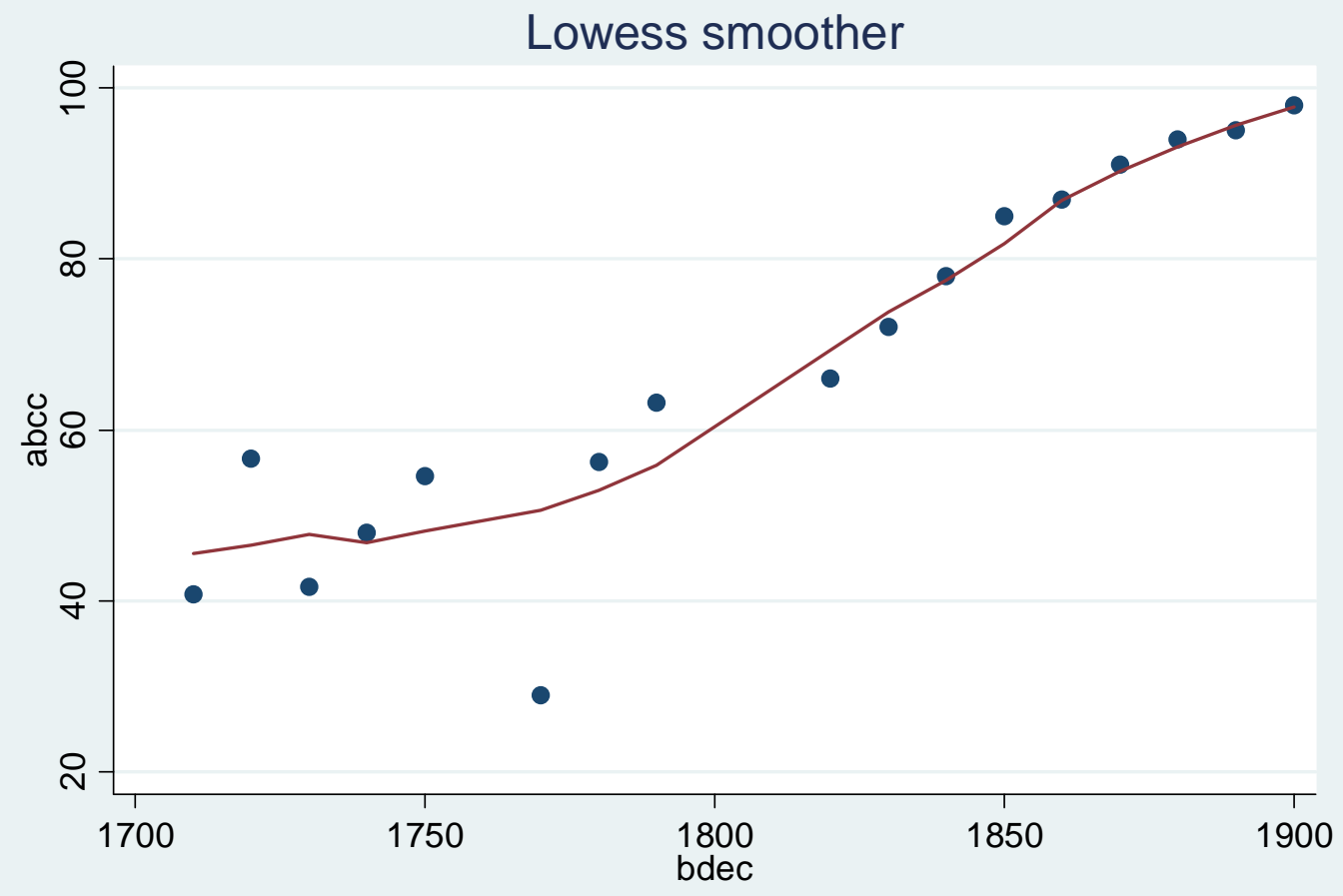

bandwidth $=.5$ 
Figure 8: Eastern European ABCC estimates in comparison

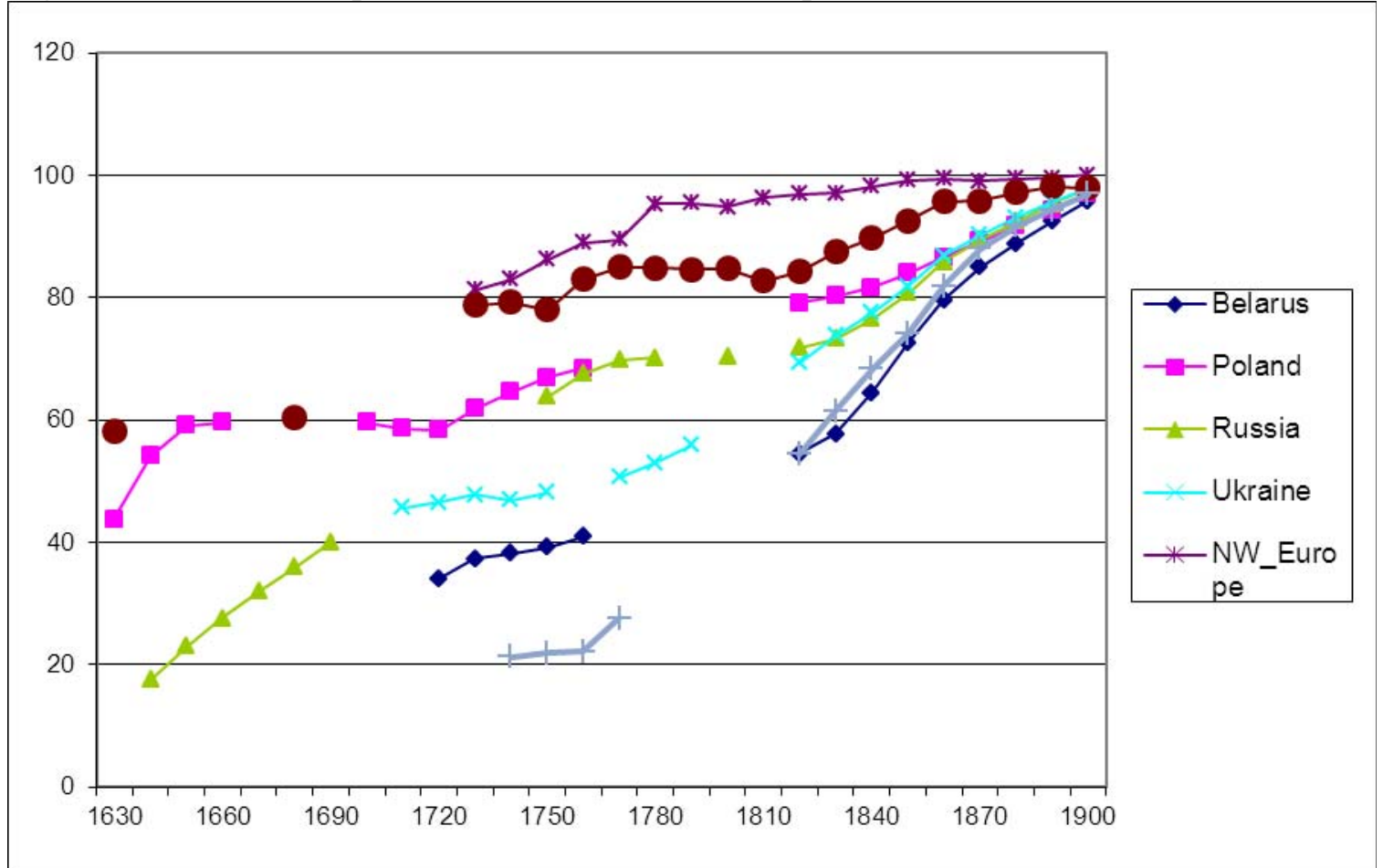

Sources for NW and S Europe: Stolz et al. (2012), see also Tollnek and Baten (2011); Southern Europe in 1630 (1680) refers to the average value of Spain and Portugal during the period 1600-49 (1650-99), see Juif and Baten (2001). 
Table A.1: ABCC by region (raw values), and regional adjustment factors

Adj.factor

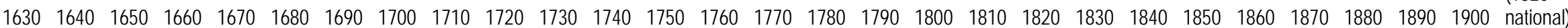

\section{Russia}

Eyskij

Moskovskij

Orenburgskij

Tulskij

Vjatskij

Russia

\section{Poland-East (later Russian)}

\begin{tabular}{|c|c|c|c|c|c|}
\hline Chenstohovskij & & & 66 & 60 & 73 \\
\hline Kaliskij & & 76 & 77 & 72 & 71 \\
\hline Warschavskij & 57 & 41 & 50 & 67 & \\
\hline
\end{tabular}

Warschavski

\section{Poland-West (19th C Austria/Prussia)}

Ermland-

$\begin{array}{lllll}\text { Masuren } & 62 & 49 & 84 & 83\end{array}$

Cracow_County

Posen

Oppeln

Pomerania

Poland-West (19th C Austria/Prussia)

\section{Belarus}

\section{Bobrujskij}

Gomelski]

Minskij

Pinskij

Belarus

\section{Lithuania}

Vilenskij

\section{$\begin{array}{lll}66 & 68 \quad 69\end{array}$}

$\begin{array}{llll}62 & 73 & 79 & 78\end{array}$

$$
\begin{array}{llllll}
45 & 48 & 59 & 61 & 57 & 51
\end{array}
$$$$
\begin{array}{lllll}
26 & 35 & 32 & 33 & 38
\end{array}
$$

\begin{tabular}{|c|c|c|c|c|c|c|}
\hline & & 34 & 62 & 75 & 75 & 81 \\
\hline & & 66 & 71 & 82 & 83 & 86 \\
\hline & & & & 83 & 93 & 97 \\
\hline 83 & 77 & 85 & 87 & 93 & & \\
\hline
\end{tabular}

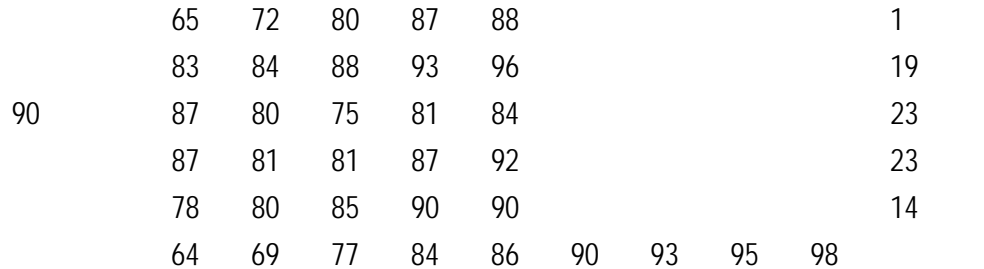

$\begin{array}{lllllllll}64 & 69 & 77 & 84 & 86 & 90 & 93 & 95 & 98\end{array}$

\section{Lithuania}

\section{Ukraine}

Charkovskij

Kossow

Krasnystaw

Przemyshlany

$\begin{array}{llllllllll}98 & 88 & 89 & 90 & 95 & 91 & & & & 11 \\ 92 & 97 & 95 & 100 & 98 & & & & & 20 \\ 92 & 92 & 93 & 95 & 97 & & & & & 15 \\ 93 & 93 & 93 & 95 & 98 & & & & & \\ 98 & 97 & 98 & 98 & 98 & & & & & \\ & 77 & 78 & 80 & 86 & 87 & 88 & 92 & 94 & 97 \\ \end{array}$

$\begin{array}{llllllllll}48 & 54 & 63 & 75 & 81 & & & & & -2 \\ 50 & 59 & 70 & 82 & 84 & & & & & 0 \\ 55 & 60 & 66 & 77 & 81 & & & & & 5 \\ 57 & 62 & 68 & 80 & 80 & & & & & 7 \\ 50 & 55 & 63 & 75 & 82 & 84 & 90 & 92 & 96 & \end{array}$

$\begin{array}{lllllll}69 & 68 & 71 & 82 & 87 & 10\end{array}$ $\begin{array}{lllllllll}59 & 61 & 62 & 74 & 86 & 89 & 92 & 94 & 97\end{array}$

(2)


Table A2: ABCC by region (regionally adjusted values)

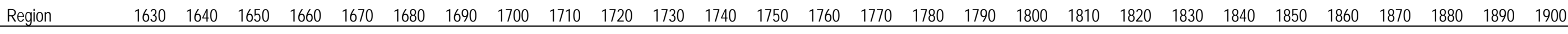

Russia

$\begin{array}{llll}61 & 71 & 78 & 76\end{array}$

Eyskij

Moskovskij

$48 \quad 49 \quad 50$

Orenburgskij

$\begin{array}{lllllll}\text { Tulskij } & 23 & 25 & 37 & 38 & 34 & 28\end{array}$

$\begin{array}{lllllll}\text { Vjatskij } & 13 & 21 & 19 & 20 & 25 & \\ \text { Russia } & 18 & 23 & 28 & 35 & 36 & 39\end{array}$

Poland-East (later Russian)

Chenstohovskij

Kaliskij

Warschavskij

Poland-East

Poland-West (19th C Austria/Prussia)

Ermland-

Masuren

$\begin{array}{llll}51 & 38 & 73 & 72\end{array}$

Cracow_county

Posen

Oppeln

Pomerania

$\begin{array}{lllll}\text { Poland-West } & 51 & 38 & 73 & 72\end{array}$

$\begin{array}{lllll}63 & 57 & 65 & 67 & 73 \\ 63 & 57 & 44 & 55 & 66\end{array}$

$\begin{array}{llll}61 & 71 & 78 & 76\end{array}$

\section{Belarus}

Bobrujskij

Gomelskij

Minskij

Pinski]

Belarus

$\begin{array}{lllll}26 & 36 & 39 & 37 & 30\end{array}$

Lithuania

$\begin{array}{lllll}42 & 41 & 48 & 51 & 45\end{array}$

$\begin{array}{lllll}38 & 29 & 32 & 35 & 29\end{array}$

$\begin{array}{lllll}31 & 43 & 44 & 47 & 41 \\ 34 & 37 & 41 & 42 & 36\end{array}$

Uthuania

$21 \quad 23-25$

Charkovskij

Kossow

Krasnystaw

Przemyshlany

Ukraine

\begin{tabular}{lllll}
41 & 43 & 52 & 58 & 66 \\
& & & & \\
& 70 & 72 & 71 & 73 \\
& & 1 & 14 & 25 \\
41 & 57 & 42 & 48 & 55 \\
\hline
\end{tabular}

\begin{tabular}{lll} 
& 71 & \\
29 & 42 & 63 \\
& & \\
29 & 56 & 63 \\
\hline
\end{tabular}

59

$55 \quad 63$

$\begin{array}{lllllll}3 & 75 & 82 & 84 & 90 & 92 & 96\end{array}$

\begin{tabular}{lllllllll}
66 & 72 & 78 & 85 & 87 & 91 & 94 & 95 & 98 \\
\hline
\end{tabular}

